\title{
Pengaruh Penambahan Jenis Tepung dan Perbandingan Kosentrasi Bubur Jagung (Zea mays L.) dan Ampas Wortel (Daucus carota L.) terhadap Mutu Sensori Tortilla Chips
}

\author{
(The Effect of Adding Flour Types and Concentration Ratio of Corn Grits (Zea mays L.) and \\ Carrot Pulp (Daucus carota L.) on Tortilla Chips Sensory Evaluation) \\ Meliza $^{1}$, Yanti Meldasari Lubis ${ }^{1}$, Fahrizal $^{1 *}$ \\ ${ }^{1}$ Program Studi Teknologi Hasil Pertanian, Fakultas Pertanian, Universitas Syiah Kuala
}

\begin{abstract}
Abstrak. Tortilla chips merupakan makanan khas dari Meksiko berbentuk keripik dengan bahan baku jagung. Tortilla chips memiliki karakteristik bentuk tipis dan mudah hancur. Penerimaan konsumen terhadap tortilla chips diukur menggunakan uji sensoris hedonik yang terdiri dari 4 uji atribut yaitu warna, aroma, rasa dan tekstur. Penelitian ini menggunakan Rancangan Acak lengkap (RAL) dengan faktorial yang terdiri dari dua faktor, yaitu : faktor pertama yaitu perbandingan bubur jagung dengan ampas wortel (P) yang terdiri 3 taraf yaitu: 70:30\%, 75:25\%, 80:20\%. Faktor kedua yaitu jenis tepung (M) yang digunakan yang terdiri 2 taraf yaitu tepung mocaf $100 \%$ dan meizena $100 \%$. Faktor perbandingan bubur jagung dan ampas wortel (P) berpengaruh sangat nyata terhadap atribut warna dan atribut tekstur, serta berpengaruh nyata terhadap atribut aroma. Berdasarkan hasil uji sensori didapatkan perlakuan terbaik yaitu perlakuan tepung maizena $100 \%$ dan perbandingan bubur jagung dan ampas wortel 75\%:25\% (M2P2).
\end{abstract}

Kata kunci: bubur jagung, ampas wortel, tepung mocaf, meizena, tortilla chips.

Abstract. Tortilla chips are typical foods from Mexico in the form of chips with corn raw material. Tortilla chips have the characteristics of a thin and easily destroyed. Consumer acceptance of tortilla chips is measured using a hedonic sensory test consisting of 4 attribute tests namely color, aroma, taste and texture. This study uses a completely randomized design (CRD) with factorial consisting of two factors, namely: the first factor is the comparison of grits with carrot pulp (P) consisting of 3 levels, namely: 70:30\%, 75:25\%, 80:20\%. The second factor is the type of flour (M) used which consists of 2 levels: $100 \%$ mocaf flour and $100 \%$ meizene. The comparison factor of grits and carrot pulp (P) has a very significant effect on the color and texture attributes, and also significantly affects the aroma attributes. Based on the results of sensory tests obtained the best treatment is cornstarch 100\% treatment and the ratio of corn porridge and carrot pulp 75\%: 25\% (M2P2).

Keywords: grits, carrot pulp, mocaf flour, meizena, tortilla chips.

\section{PENDAHULUAN}

Tortilla chips merupakan makanan khas dari Meksiko berbentuk keripik dengan bahan baku jagung. Tortilla berupa sejenis keripik atau chips yang terbuat dari jagung berbentuk bundar gepeng dengan ketebalan yang berbeda-beda. Tortilla chips harus dibuat dalam tingkat kerenyahan yang tinggi sehingga menjadi daya tarik bagi konsumen terhadap tekstur tortilla (Febrianto et al, 2014).Menurut Budijano et al. (2010), tortilla chips memiliki kadar air yang rendah yaitu 3-5\%. Kerusakan bahan pangan dengan kadar air rendah sering dikait dengan perubahan tekstur atau stabilitas proses oksidasi. Pada pembuatan tortilla chips tidak memiliki standar yang khusus.

Jagung (Zae mays L.)merupakan salah satu komoditi yang banyak terdapat di Indonesia dan memiliki potensi yang cukup besar sebagai sumber karbohidrat yangberupa tepung dan pati jagung untuk pembuatan produk pangan baru.Kandungan nutrisi jagung tidak kalah dari kandungan nutrisi yang terdapat dalam terigu, bahkan jagung memiliki keunggulan seperti mengandung serat pangan, unsur Fe dan $\beta$-karoten(pro vitamin A) (Suarni, 2009). 
Jagung juga mempunyai pigmen kuning alami (karatenoid) yang mengandung lutein dan zeaxantin (Febrianto et al, 2014).

Menurut Salim (2011), kandungan serat dalam tepung mocaf lebih tinggi dibandingkan dengan terigu yaitu sebanyak 3,4 gram per 100 gram tepung terigu. Menurut Wardani (2011), kandungan pati yang terdapat didalam tepung mocaf sangat tinggi 72,3\% dengan amilopektin 75\% dan amilosa 25\% dengan karakteristik viskositas (daya rekat), kemampuan gelasi, daya rehidrasi, dengan kemampuan larut yang lebih baik.Menurut Sari dan Bahar (2014), perpaduan antara tepung mocaf dan puree wortel akan menghasilkan stick yang cukup renyah, padahal kandungan air yang terdapat didalamnya cukup tinggi.

Wortel (Daucus carota L) salah satu sayuran yang banyak mengandung provitamin A. $\beta$-karoten pada wortel merupakan prekursor pembentukan vitamin A yang berfungsi sebagai anti oksidan untuk menangkal radikal bebas (Muzaki et al., 2017).Menurut susanti (2017), Wortel mengandung sekitar $15.00 \mathrm{IU} \beta$-karoten. Menurut Wibowo et al, (2014) Serat wortel memiliki total yang tinggi 46,95 \% bk, dengan IDF 41,29 \% dan SDF 5,66 \% bk sehingga termaksud sayuran dengan serat tidak larut yang tinggi.

\section{METODE PENELITIAN}

\section{Tempat dan Waktu Penelitian}

Penelitian ini dilaksanakan pada bulan januari Tahun 2019, di Laboratorium Rekayasa Proses Pangan dan Industri, Laboratorium Uji Sensori dan Laboratorium Analisis Pangan dan Hasil Pertanian Prodi Teknologi Hasil Pertanian, Fakultas Pertanian Universitas Syiah Kuala.

\section{Bahan dan Alat}

Bahan-bahan yang digunakan dalam penelitian ini adalah tepung mocaf merek Prodes yang didapat dari online shoping, maizena merek Pore cornflour didapat dari pasar Peunayong, jagung pipil didapat dari toko Bogor, ampas wortel didapatkan dari penjual jus di Darussalam, bawang putih, merica, garam dapur, kapur sirih, baking powder, minyak goreng, dan air. Bahan kimia yang digunakan untuk analisis antara lain: dietil eter, aquades, $\mathrm{NaOH}$, $\mathrm{HCL}$, alkohol, $\mathrm{H}_{2} \mathrm{SO}_{4}$ dan etanol $95 \%$.

Alat yang digunakan dalam penelitian ini adalah panci presto/ dandang, timbangan digital, blender, gilingan mie, wajan, wadah plastik, pisau, tampah, loyang, kompor, sendok, kain lap. Sedangkan alat yang digunakan untuk analisis adalah oven, soxhlet, desikator, cawan porselen, erlenmeyer, oven, tanur, kertas saring, cawan petri dan beaker glass.

\section{Rancangan Penelitian}

Penelitian ini menggunakan Rancangan Acak lengkap (RAL) dengan faktorial yang terdiri dari dua faktor, yaitu : faktor pertama yaitu jenis tepung $(\mathrm{M})$ yang digunakan terdiri dari tepung mocaf $100 \mathrm{~g}$ dan maizena $100 \%$. Faktor keduanya perbandingan bubur jagung dan ampas wortel yang terdiri 3 taraf (P) yaitu: 70:30 \%, 75:25\%, 80:20\%. Kombinasi perlakuan adalah $2 \times 3=6$ kombinasi perlakuan yang masing-masing diulang sebanyak 3 kali ulangan sehingga diperoleh 18 satuan percobaan.

\section{Analisis Data}

Analisis data yang digunakan secara statistik menggunakan Microsoft Excell dan olahan data secara ANOVA (Analysis of Variance).Perlakuan yang berpengaruh dilanjutkan dengan uji lanjut Duncan Multiple Range Test (DMRT). 


\section{Analisis Produk}

Tortilla chipsdianalisis menggunakan Uji sensori penerimaan konsumen menggunakan metode hedonik yang meliputi 4 atribut warna, aroma, tekstur, dan rasa(Asmoro et al., 2017).

\section{Prosedur Penelitian}

Proses Perendaman dan Proses Perebusan Biji Jagung (Modifikasi Lawalata et al., 2017), ditimbang biji jagung sebanyak $1 \mathrm{~kg}$. Direndam didalam air sebanyak 1 liter air dan dilarutkan kapur sirih sebanyak 2 gram dan air 50 ml.Dicampur larutan kapur dan air 1 liter kedalam wadah dan diaduk sampai tercampur, masukan biji jagungkedalam larutan kapur dan direndam selama 24 jam.Dicuci sampai bersih dan ditiriskan.Ditambah garam 5 gram, diaduk sampai larut.Ditimbang biji jagung sebanyak $1 \mathrm{~kg}$ dan dimasukkan kedalam larutan air garam.Direbus biji jagung dengan menggunakan api hingga suhu mencapai $100^{\circ} \mathrm{C}$, dan dibiarkan selama 1 jam.Ditiriskan biji jagung, tunggu sampai biji jagung dingin.

Cara Pembuatan adonandan Penggorengan tortilla chips(Monifikasi Wulandar, 2016 dan Lawalata et al., 2017), biji jagung yang telah ditiriskan, digiling menggunakan blender hingga halus dengan menambahkan $500 \mathrm{ml}$ air. Ampas wortel kedalam wadah plastik, dan ditimbang ampas wortel sebanyak 30,25, dan $20 \mathrm{~g}$, dan bubur jagung ditimbang sebanyak 70, 75, dan $80 \mathrm{~g}$, dan ditimbang $5 \mathrm{~g}$ garam, $5 \mathrm{~g}$ bawang putih dan $5 \mathrm{~g}$ merica, dan baking powder 2 g.Dicampurkan masing-masing bahan tambahan, bubur jagung dan ampas wortel dengan perbandingan 70:30, 75:25, dan 80:20, dan dimasukkan kedalam wadah plastik. Diaduk hingga tercampur merata, kemudian ditambahkan tepung (tepung mocaf dan maizena) sebanyak 100 g pada masing-masing perlakuan, diaduk sampai kalis.Dibentuk adonan hingga membentuk lembaran, kemudian dipotong-potong berbentuk kotak dengan ukuran $3,5 \times 2,5$.Tortilla chips yang basah dimasukkan kedalam oven dengan suhu $80^{\circ} \mathrm{C}$ selama 2 jam hingga kadar air tortilla berkurang.Dipanaskan minyak goreng kedalam wajan sebanyak 500 ml kemudian, Tortilla chips basah digoreng dengan minyak panas hingga kuning kecoklatan, kemudian ditiriskan tortilla chips.Dilakukan uji hedonik meliputi parameter warna, aroma, tekstur dan rasa dari masing-masing perlakuan

Uji organoleptik (Asmoro et al., 2017): setelah tortilla chips digoreng, dilakukan pengujian penerimaan yaitu uji hedonik yang meliputi 4 atribut (warna, aroma, rasa dan tekstur). Pengujian ini dilakukan oleh 30 panelis semi terlatih yaitu mahasiswa THP Unsyiah angkatan 2014 dan 2015 yang telah lulus mata kuliah evaluasi sensoris. Pengujian ini menggunakantabel kusioner dengan skala 1 sampai 5 , yaitu $1=$ sangat tidak suka, $2=$ tidak suka, 3 = netral, 4 = suka, 5 = sangat suka.Penilaian sampel tortilla chips dimulai dari kiri ke kanan pada baris pertama dan dilakukan penilaian dengan memberikan tanda $(\sqrt{ })$ untuk setiap kode. Setelah mencicipi 1 sampel dilakukan penetralan indra pengecapan dengan air putih dan crackers tawar, serta tidak membandingkan satu sampel dengan lainnya. Data dari tabel kusioner ditabulasi dan ditentukan nilai mutunya dengan mencari rerata pada setiap panelis dengan tingkat kepercayaan 95\% (sesuai standar SNI).

\section{HASIL DAN PEMBAHASAN}

\section{Analisis Sensoris (Hedonik)}

Pengujian sensoris atau pengujian dengan indra atau dikenal dengan pengujian organoleptik sudah ada sejak manusia mulai menggunakan indranya untuk menilai kualitas dan keamanan suatu produk. Salah satu metode pengujian yaitu uji afeksi yang terdiri dariuji penerimaan yaitu penilaian seseorang terhadap sifat atau kualitas bahan yang menyebabkan

Pengaruh Penambahan Jenis Tepung dan Perbandingan Kosentrasi Bubur Jagung (Zea mays L.) dan Ampas Wortel (Daucus carota L.) terhadap Mutu Sensori Tortilla Chips (Meliza, Yanti Meldasari Lubis, Fahrizal) Jurnal Ilmiah Mahasiswa Pertanian, Vol. 4, No.4, November 2019: 329-336 
orang menyukai dan untuk mengetahui apakah komoditas tertentu dapat diterima oleh masyarakat. Uji kesukaan (uji hedonik) termasuk ke dalam kelompok uji penerimaan, dimana panelis diminta tanggapan pribadinya tentang kesukaan serta tingkat kesukaan serta kebalikannya (Setyaningsih et al., 2010).Skala hedonik dapat direntangkan atau diciutkan menurut skala yang dikehendaki serta dapat diubah ke dalam skala numerik.Skala yang seimbang yaitu jumlah yang ganjil.

Persyaratan analisis sensori dengan mempertimbangkan beberapa faktor seperti: panelis, laboratorium uji, persiapan dan penyajian, metode penilaian dan analisis data. Panelis merupakan perseorangan atau kelompok yang menilai secara subjektif mutu organoleptik produk sesuai prosedur, terdapat beberapa jenis panelis yaitu panelis perseorangan, panelis terbatas (3-5 orang ahli), panelis terlatih (15-25 orang), panelis semi terlatih (15-25 orang), panelis tidak terlatih (lebih dari 25 orang), panelis konsumen (30-100 orang), dan panelis anak-anak dengan usia 3-10 tahun. Laboratorium uji mutu organoleptik harus memiliki bagian dapur, bilik pencicip, suhu ruangan yang nyaman, pencahayaan yang bagus, warna dinding dan sarana yang netral. Persiapan dan penyajian produk diawali dengan penjelasan tujuan dan cara pengujian, lalu dilakukan penyajian dengan memperhatikan estetika seperti, ukuran produk, kode produk, jumlah contoh yang sama, dan suhu produk yang disajikan (Kusuma et al., 2017).

\section{Warna}

Warna merupakan salah satu atribut yang akan menentukan secara langsung dengan indera penglihatan yang dilakukan oleh panelis. Dari hasil penelitian yang diperoleh nilai warna berkisaran antara 2,93-3,58 (netral sampai suka) dengan nilai rata-rata 3,38 (netral sampai suka). Hasil sidik ragam menunujukkan bahwa faktor perbandingan bubur jagung dan ampas wortel $(\mathrm{P})$ berpengaruh sangat nyata $(\mathrm{P} \leq 0,05)$, faktor jenis tepung $(\mathrm{M})$ dan interaksi keduanya tidak berpengaruh nyata (MP) $(\mathrm{P}>0,05)$ terhadap nilai warna tortilla chips. Pengaruh perbandingan bubur jagung dan ampas wortel $(\mathrm{P})$ terhadap atribut warna tortilla chipsdilihat pada Gambar 1.

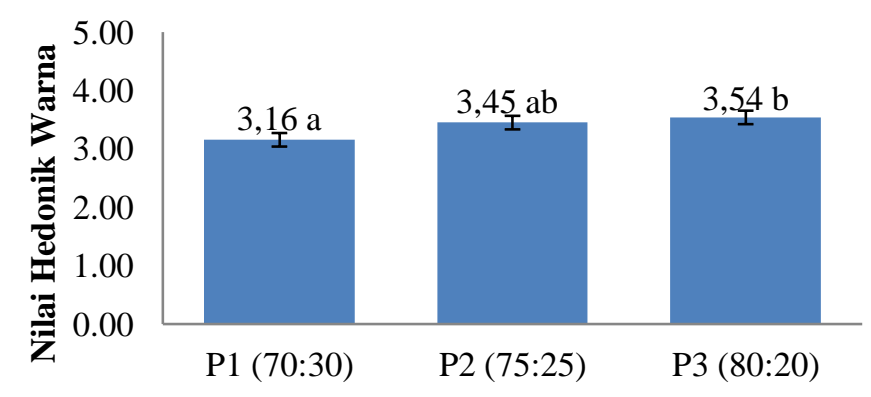

Perbandingan Bubur Jagung : Ampas Wortel \%

Gambar 1. Pengaruh perbandingan bubur jagung dan ampas wortel tortilla chipsterhadap organoleptik warna tortilla chipspada $\mathrm{DMRT}_{0.05}$ taraf $1=0,28$, taraf $2=0.30$, dan $\mathrm{KK}=6.75 \%$ (nilai yang diikuti huruf yang sama menunjukan perbedaan yang tidak nyata).

Hasil uji DMRT menunjukkan skor atribut warna pada perlakuan P1(70\%:30\%) yaitu 3,16 (netral sampai suka) yang menunjukkan perbedaan tidak nyata dengan skor perlakuan P2(75\%:25\%) yaitu 3,45 dan P3(80\%:20\%) yaitu 3,54 (netral sampai suka). Panelis lebih menyukai tortilla chips dengan rasio bubur jagung dan ampas wortel dengan perlakuan

Pengaruh Penambahan Jenis Tepung dan Perbandingan Kosentrasi Bubur Jagung (Zea mays L.) dan Ampas Wortel (Daucus carota L.) terhadap Mutu Sensori Tortilla Chips (Meliza, Yanti Meldasari Lubis, Fahrizal) Jurnal Ilmiah Mahasiswa Pertanian, Vol. 4, No.4, November 2019: 329-336 
P3(80\%:20\%), hal ini diduga karena tortilla chipsberwarna coklat keemasan yang hampir sama dengan tortillayang dijual. Sedangkan tortilla chipsdengan perlakuan P1(70\%:30\%) dan P2(75\%:25\%) berwarna coklat sedikit keemasan. Hal ini diduga karena banyaknya persentase bubur jagung dan ampas wortel yang ditambahkan menghasilkan warna keemasan pada tortilla chips.

Pada penelitian yang telah dilakukan, panelis lebih suka pada tortilla dengan jumlah bubur jagung lebih banyak dari ampas wortel. Hal ini karena perubahan warna pigmen kuning pada jagung pada saat perendaman dengan air kapur menjadi lebih cerah, sehingga dapat mempengaruhi warna akhir dari tortilla. Tetapi setelah dilakukan penggorengan warna yang dihasilkan tortilla menjadi berubah, tortilla yang dihasilkan berwarna kecoklatan, hal ini dikarenakan terjadi interaksi asam amino dengan karbohidrat sehingga menimbulkan perubahan warna pada tortilla.

\section{Aroma}

Faktor yang mempengaruhi aroma adalah kualitas komponen aroma, suhu, komposisi aroma, viskositas makanan, interaksi alami antar komponen dan komponen nutrisi dalam makanan tersebut seperti protein, lemak dan karbohidrat. (Marsigit et al., 2017).

Hasil skor atribut aroma tortilla chipsberkisaran anatara 3,21- 3,61 (Netral sampai Suka) dengan rata-rata 3,50 (Netral sampai Suka). Hasil analisis sidik ragam menunjukkan bahwa faktor perbandingan bubur jagung dan ampas wortel $(\mathrm{P})$ berpengaruh nyata $(\mathrm{P}>0,01)$ terhadap atribut aroma tortilla chips. Perlakuan jenis tepung dan interaksi antara jenis tepung dan rasio bubur jagung dan ampas wortel tidak berpengaruh sangat nyata $(P>0,01)$ terhadap nilai aroma tortilla chips, dapat diihat pada Gambar 2.

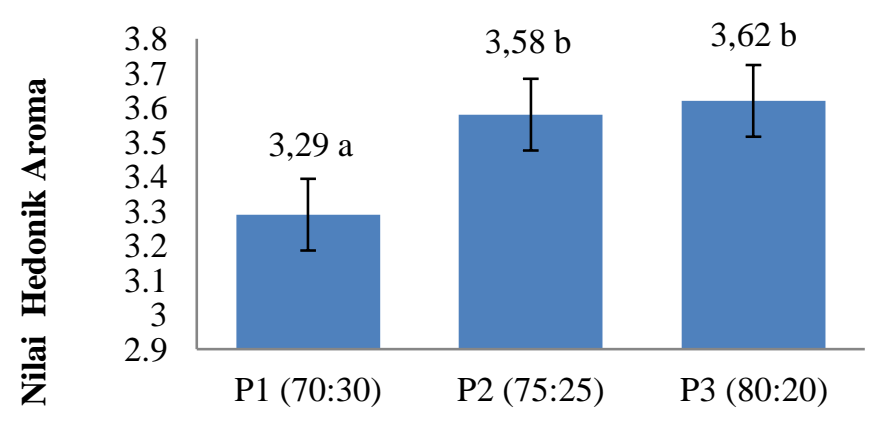

Perbandingan Bubur Jagung : Ampas Wortel \%

Gambar 2. Pengarug perbandingan bubur jagung dan ampas wortel terhadap organoleptik tekstur tortilla chipspada $\mathrm{DMRT}_{0.01}$ taraf $1=0.23$, taraf $2=0.24$, dan $\mathrm{KK}=3.79 \%$ (nilai yang diikuti huruf yang sama menunjukan perbedaan yang tidak nyata).

Berdasarkan uji lanjut DMRT yang dapat dilihat pada gamabar diatas menunjukkan skor atribut aroma terendah terdapat pada perlakuan P1(70\%:30\%) yaitu 3,29 (netral) yang berbeda nyata dengan P2(75\%:25\%) yaitu 3,58 dan P3(80\%:20\%) yaitu 3,62 (suka). Sedangkan pada perlakuan P2 dan P3 menunjukkan perbedaan yang tidak nyata dengan P1, untuk aroma panelis lebih menyukai tortilla chips pada perlakuan P3. Hal ini karena penambahan bubur jagung yang lebih banyak dari pada ampas wortel dapat mempengaruh aroma tortilla chipsyang lebih beraroma sehingga panelis lebih menyukai aroma tortillachips pada perlakuan P3(80\%:20\%) yaitu 3,62. P2(75\%:25\%) tidak berbeda nyata dengan 
perlakuan P3(80\%:20\%) dan sangat berbeda nyata dengan perlakuan P1(70\%:30\%), hal ini diduga pengaruh banyaknya perbandingan bubur jagung dapat membuat tortillachips lebih beraroma.

\section{Tekstur}

Tekstur salah satu sifat fisik dari suatu bahan yang dapat dirasakan oleh indera perasa (lidah) dan perasa (kulit). Hasil uji organoleptik yang telah dilakukan kesukaan panelis terhadap tekstur tortilla chipsberkisaran 2,97 - 3,49 (Netral sampai Suka) dengan rata-rata 3,21 (Netral sampai Suka). Rata-rata penilaian kesukaan panelis terhadap tortilla chipsmenghasilkan kriteria netral, hal ini dikarenakan tekstur tortilla yang dihasilkan sangat mudah hancur dan patah, sehingga panelis cenderung kurang suka terhadap teksturnya. Hasil analisis sidik ragam menunjukkan bahwa perlakuan perbandingan antara rasio bubur jagung dan ampas wortel $(\mathrm{P})$ berbeda nyata $(\mathrm{P} \leq 0,01)$ terhadap organoleptik tekstur dari tortilla chips. Perlakuan jenis tepung dan interaksi antara jenis tepung dan rasio bubur jagung dan ampas wortel tidak berpengaruh sangat nyata $(\mathrm{P}>0,01)$ terhadap nilai aroma tortilla. Pengaruh rasio bubur jagung dan ampas wortel (P) terhadap organleptik tekstur tortilla chips, dapat dilihat pada Gambar 3.

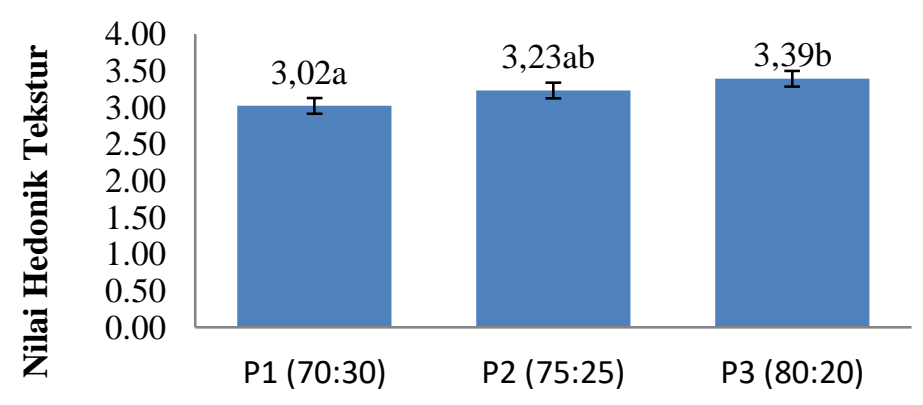

Perbandingan Bubur Jagung : Ampas Wortel \%

Gambar 3. Pengaruh perbandingan bubur jagung dan ampas wortel terhadap organoleptik tekstur tortilla chip pada DMRT $_{0.01}$ taraf $1=0.26$, taraf $2=0.27$, dan $\mathrm{KK}=4.70 \%$ (nilai yang diikuti huruf yang sama menunjukan perbedaan yang tidak nyata).

Berdasarkan uji DMRT terhadap organoleptik tekstur tortilla chips menunjukkan perlakuan P1(70\%:30\%) memiliki nilai paling rendah dan perlakuan P3(80\%:20\%) paling tinggi.Tortilla chipspada perlakuan P2(75\%:25\%) memiliki nilai sebesar 3,23 dan perlakuan P3(80\%:20\%) memiliki nilai tertinggi yaitu 3,39. Pada perlakuan P1(70\%:30\%) berbeda nyata dengan perlakuan P2(75\%:25\%) dan tidak berbeda nyata dengan perlakuan P3(80\%:20\%). Berdasarkan gambar dapat disimpulkan semakin tinggi rasio bubur jagung dan ampas wortel, maka panelis menilai semakin tinggi tigkat kerenyahan yang dihasilkan oleh tortilla chips.

Tekstur dapat diamati dengan mulut (pada waktu digigit, dikunyah, dan ditelan) atau perabaan dengan jari. Kerenyahan diduga karena dalam butiran pati jagung rantai-rantai amilosa dan amilopektin tersusun dalam bentuk semi kristal yang menyebabkan tidak larut dalam air, dengan adanya perlakuan pemanasan dan perendaman struktur kristal rusak dan rantai polisakarida akan mengambil posisi acak segingga menyebabkan tergelatinisasi sempurna. Tekstur tortilla dengan perendaman larutan kapur berkisaran antara 3,30 hingga 3,85 (Febrianto et al., 2014). 


\section{Rasa}

Rasa merupakan parameter mutu yang terditeksi oleh panelis melalui alat pengecap yaitu lidah. kesukaan rasa pada tortilla chipsmerupakan faktor yang penting untuk diamati setelah penampakan. Pada penelitian ini, nilai rasa pada tortilla chips yang dihasilkan berkisaran dari 3,04 - 3,52 (Netral sampai suka) dengan rata-rata 3,24 (Netral sampai Suka). Hasil sidik ragam menunjukkan bahwa jenis tepung dan rasio bubur jagung dan ampas wortel tidak berpengaruh nyata $(\mathrm{P}>0,05)$ terhadap nilai rasa tortilla chips.

Menurut Ma'ruf et al., (2017), rasa sangat dipengaruhi oleh beberapa kandungan kimia yang terdapat dalam bahan dan bahan tambahan yang digunakan. Cita rasa tortilla dihasilkan dari hasil penambahan dan kombinasi rasa bahan. Selain berasal dari bahan dasar, rasa tortilla juga didapatkan melalui proses penggorengan. Minyak goreng yang digunakan dapat memberikan rasa gurih pada produk yang dihasilkan, umumnya tortilla diberikan rasa tambahan dengan memasukkan bumbu (berisi garam dan bawang putih).

\section{KESIMPULAN DAN SARAN}

Kesimpulan yang dapat diambil dari penelitian ini yaitu faktor jenis tepung (M) berpengaruh sangat nyata terhadap kadar serat tortila chips menggunakan tepung maizena, memiliki kadar air yang rendah dan kadar serat yang lebih tinggi dibandingkan penggunaan tepung mocaf.Faktor perbandingan bubur jagung dan ampas wortel (P) berpengaruh sangat nyata terhadap atribut warna dan atribut tekstur, berpengaruh nyata terhadap kadar air dan atribut aroma. Semakin tinggi bubur jagung yang digunakan maka tortilla chips yang dihasilkan memiliki kadar air yang rendah dan panelis menyukai dari segi atribut warna dan aroma.Interaksi kedua faktor (MP), jenis tepung (M) dan perbandingan bubur jagung dan ampas wortel (P) berpengaruh nyata terhadap serat kasar.Berdasarkan hasil uji organoleptik dan analisis kimia didapatkan perlakuan terbaik yaitu perlakuan tepung maizena $100 \%$ dan perbandingan bubur jagung dan ampas wortel 75\%:25\% (M2P2).Perlakuan terbaik (M2P2) tepung maizena 100\% (M2) perbandingan bubur jagung dan ampas wortel 75\%:25\% (P2) menghasilkan kadar ptotein 3,5\%, uji kekerasan 0,33g/mm, lemak 9,62\%.

Saran yang dapat diberikan setelah pelaksanaan penelitian ini yaitu diperlukan penelitian lebih lanjut bertujuan untuk memperbaiki rasa, tekstur dan aroma tortilla chips agar lebih disukai konsumen, seperti penambahan bahan baku lain agar adonan tidak pecah pada saat dicetak.

\section{DAFTAR PUSTAKA}

Alam, N., dan Nurhaeni. 2008. Komposisi Kimia dan Sifat Fungsional Pati Jagung Berbagai Varietas yang Diekstrak Dengan Pelarut Natrium Bikarbonat. Jurnal Agroland. 15(2). 89-94.

Asmoro, N. W., S. Hartati., dan C. B. Handayani. 2017. Karakteristik Fisik dan Organoleptik Produk Mocatilla Chips dari Tepung Mocaf dan Jagung. Jurnal Ilmu Pangan dan Hasil Pertanian. 1: 63-70.

Febrianto, A., Basito., dan C. Anam. 2014. Kajian Karakteristik Fisikokimia Sensori Tortilla Corn Chips dengan Variasi Larutan Alkali Pada Proses Nikstamalisasi Jagung. Jurnal Teknosains Pangan. 3: 22-34.

Imaryana., H. Merdesci., dan R. Ninsix. 2016. Formulasi Pati Jagung (Zea Mays L.) dengan Tepung Tapioka terhadap Sifat Fisikokimia Bakso Ikan Gabus (Ophiocephalus striatus). Jurnal Teknologi Pertanian. 5: 47-53.

Pengaruh Penambahan Jenis Tepung dan Perbandingan Kosentrasi Bubur Jagung (Zea mays L.) dan Ampas Wortel (Daucus carota L.) terhadap Mutu Sensori Tortilla Chips (Meliza, Yanti Meldasari Lubis, Fahrizal) Jurnal Ilmiah Mahasiswa Pertanian, Vol. 4, No.4, November 2019: 329-336 
Ibrahim., dan P. Oktavianto. 2011. Pembuatan Kerupuk Sehat dari Ampas Wortel. [Skripsi]. Program Studi Teknik Kimia, Jurusan Teknik Kimia, Fakultas Teknik. Universitas Sebelas Maret, Surakarta.

Kumalaningsih, S., Wignyanto, dan Fitria. 2005. Perancangan Unit Pengolahan Keripik Tortilla Jagung (Corn Tortilla chips) Dalam Skala Industri Kecil. Jurnal Teknologi Pertanian. 6(1): 7-16

Kusuma, T. S., A. D. Kurniawati., Y. Rahmi., I. H. Rusdan., dan R. M. Widyanto. 2017. Pengawasan Mutu Makanan. Universitas Brawijaya Press, Malang.

Lidiyawati, R., F. Dwijayanti., N. Yuswita., dan S. F. Pradigdo. 2013. Mentel (Permen Wortel) sebagai Solusi Penambah Vitamin A. Jurnal Ilmiah Mahasiswa. 3: 22-30.

Lawalata, V. N., Tanudin., dan C. G. C. Lopulalan. 2017. Pengaruh Kosentrasi Larutan Kapur $\left(\mathrm{Ca}(\mathrm{OH})_{2}\right)$ dan Lama Perebusan terhadap Mutu Tortilla Jagung. Agritekno, Jurnal Teknologi Pertanian. 6(2): 33-38.

Ma'aruf, F. H., A. Mustofa., dan N. Suhartati. 2017. Pemanfaatan Tepung Sukun (Artocarpus Communis) dalam Pembuatan Tortilla dengan Variasi Panambahn Jagung (Zea Mays) Dan Kacang Hijau (Vigna Radiata). Jurnal JITIPARI.(4):119-126.

Maflahah, I. 2010. Analisis Proses Pembuatan Pati Jagung (Meizena) Berbasis Neraca Massa. Embryo. 7: 40-45.

Marsigit,W., Bonodikum., dan L. Sitanggang. 2017. Pengaruh Penambahan Baking Powder dan Air Terhadap Karakteristik Sensoris dan Sifat Biskuit Mocaf (Modified Cassava Flour). Jurnal Agroindustri. 7(1): 1-10.

Patola, E. C., dan D. Ilminungtyas. 2017. Substitusi Pisang Kepok Putih (Musa Balbisiana) Pada Pembuatan Tortilla ChipsPisang. Jurnal Ilmiah UNTAG Semarang. 6: 23022752.

Saleh, A. 2013. Efesiensi Kosentrasi Perekat Tepung Tapioka terhadap Nilai Kalor Pembakaran pada Biobriket Batang Jagung (Zea Mays L.). Jurnal Teknosains. 7(1): 78-89.

Sari, J. M., dan A. Bahar. 2014. Pengaruh Substitusi Tepung Mocaf (Modified Cassava Flour) dan Penambahan Puree Wortel (Daucus carota L.) terhadap Sifat Organoleptik Stick. e-Journal Boga. 3(2): 26-35.

Setyaningsih, D., A. Apriyantono., dan M. P. Sari. 2010. Analisis Sensori untuk Industri Pangan dan Agro. IPB Press, Bogor

Syafutri, M. I. Dan E. Lidiasari. 2014. Pengaruh Kosentrasi Penambahan Tepung Tempe Terhadap Karakteristik Tortilla Labu Kuning. Jurnal Teknologi Industri dan Hasil Pertanian. 19: 289-296.

Suarti, B., M. Fuadi., dan W. D. Rasih. 2015. Penambahan Natrium Bikarbonat (Nahco3) dan Suhu Pengeringan terhadap Mutu Tortila Biji Durian (Durio zibethinus Murr). Agrium 19: 0852-1077.

Sobari, E., dan F. Fathurohman. 2017. Efektivitas Penyiangan terhadap Hasil Tanaman Wortel (Daucus carota L.) Lokal Cipanas Bogor. Jurnal Biodjati. 2: 11-21. 